\title{
A Regional Approach to Rural Development? Regional and Rural Programmes in Poland 2007-2015
}

\begin{abstract}
We explore the role of structural factors (i.e. place-based characteristics) in shaping EU policy. Our analysis covered the real expenditure of funds for individual priority axes in the programmes of both policies in the 2007-2015 period (according to $\mathrm{N}+2$ rule) and the change in socio-economic features at the local (powiat, NUTS4) level. The Pearson correlation coefficient was used to assess the relationship between the level of per capita expenditure on RDP (rural development programmes) and ROP (regional operational programmes) and selected indicators describing the level of economic, social and demographic development of local government units. We show that in 20072013 rural and regional policy instruments were complementary, but also strongly related to the characteristics of the region (such as size, population, farmland) and therefore require greater adaptation to development opportunities and limitations. We suggest that there should be a more a place-based approach in future rural policy design and implementation.
\end{abstract}

Keywords: regional policy, CAP, complementariness, regional analysis, public policy, rural development programme, regional operational programme, 2007-2015, Poland.

\section{Introduction}

According to a number of studies (Barca 2009; Crescenzi, De Filippis and Pierangeli 2015; Esposti 2008; Monasterolo 2012; Tacoli 2006), urban and rural areas are increasingly interconnected. Policy measures for urban development should therefore take account of the characteristics and effects (also unintentional) of path dependency for rural areas. At the same time, the development gap in several

Paweł Chmieliński, PhD, Institute of Agricultural and Food Economics - National Research Institute (IERiGŻ-PIB), Świętokrzyska 20, 00-002 Warsaw, pawel.chmielinski@ierigz.waw.pl; Marcin Gospodarowicz, PhD (dr hab.), Institute of Agricultural and Food Economics - National Research Institute (IERiGŻPIB), Świętokrzyska 20,00-002 Warsaw, marcin.gospodarowicz@ierigz.waw.pl. 
EU regions is widening in terms of development opportunities, whereas in most of the EU poverty is still concentrated in rural areas (Brasili and Fanfani 2007; Monasterolo 2012).

Regional problems originate from rural areas, and solutions for urban problems may be found in a redefinition of the relation between urban and rural areas (see the issue of sustainable mobility, short food chains, new business models). Therefore, a proper understanding of such interdependences can contribute to better addressing the issues both specific to rural and urban areas in modern policies. Moreover, there is a need for integration of rural and regional approaches that can elicit new opportunities for synergies and complementarities in research and policy (Charron, Dykstra and Lapuente 2013).

The resulting need to embed the planning process of all EU policies in the context of their regional impact is a challenge for successive reforms of the CAP and cohesion policy. This connects with the optimal allocation of funds under both policies, emphasising the demarcation lines that determine the mutual complementarity of measures. The discussion on the future shape of the EU policies involves the need to develop an evidence-based policy recommendation, based on purely scientific analysis but with practical commentary, which will be the premise for the better design of rural and regional policy (Barca, McCann and RodríguezPose 2012; Checkel 2005).

Which paradigm prevails is still questioned and only a limited amount of research has currently been conducted on this crucial issue (Collins et al. 2017). Building upon the approach by Crescenzi, De Filippis and Pierangeli (2015), this empirical analysis explores the role of structural factors (i.e. place-based characteristics) in shaping the EU policy. We analyse the real expenditure of funds for individual priority axes in both policy programmes in the 2007-2015 period (in accordance with the $\mathrm{N}+2$ rule), as well as the change in socio-economic characteristics at the local level (powiat, NUTS4) during this period. Pearson's correlation coefficient served to assess the relationship between the level of RDP (rural development programme under the pillar II of CAP) and ROP (16 regional operational programmes) per capita expenditure and selected indicators describing the level of economic, social and demographic development of individual powiats in Poland. The analysis considers the shape of the policy in terms of the allocation of funds the effects of these allocations (on change in socio-economic features) and the interaction between cohesion and agricultural policy in the context of regional development. 


\section{Materials and method}

The assumption of the work is to analyse interdependencies between the Common Agricultural Policy and cohesion-policy tools directly affecting the development of the regions and the countryside, omitting measures in both policies that indirectly (though no less significantly) affect local development. In the case of cohesion policy, national (sectoral) programmes that aimed at the implementation of large-scale (e.g. infrastructural) projects of supra-regional scope were omitted, while for the CAP the first pillar of the policy, whose instruments affect rural systems mainly as part of farmers' investments and household budgets, was not considered. In addition, the objectives and assumptions of the second pillar of CAP instruments and regional programmes under cohesion policy are characterised by diversification of support for various transformation processes in the regional and rural dimension, thus solutions closer to a place-based factors approach.

We decided to conduct a study at the level of one country, concerning cohesionpolicy instruments and the CAP with a bearing on socio-economic development at the regional and local level (Charron, Lapuente and Rothstein 2013; Lagendijk and Cornford 2000; Roberts 1993; Suddaby and Greenwood 2005).

Studies usually show a weak connection between policy tools. For example, Becker, Egger and von Ehrlich (2010), Collins et al. (2017), Crescenzi, De Filippis and Pierangeli (2015), Crescenzi and Giua (2014), Le Gallo, Dall'Erba and Guillain (2011) argue that there are weak proofs for synergies/trade-offs between CAP and cohesion policy at the EU level, and some of those studies present positive per capita GDP growth effects of Objective 1 transfers, but with no significant employment-growth effects and no statistically significant effect of CP on economic growth. Moreover, EU policy areas and their degree of compatibility with the objective of the EU territorial cohesion crucially depend upon appropriate "place-based" allocation mechanisms, and structurally disadvantaged regions attract synergies between overall rural policy and cohesion policy expenditure.

The study is based on the approach by Shucksmith, Thomson and Roberts (2005), and comments by Pelucha, Kveton and Jilkov (2013) on this study, suggesting the need for national-level rather than an EU-wide approach in analysing the CAP impact on the regions. Pelucha and collaborators (2013) argue that relative importance of rural development measures varies widely between the EU member states - different national priorities and national budget constraints. Moreover, the study needs to be extended by other relevant socio-economic indicators, and these are available in national public statistics rather than at the EU level. This calls for the local-level analysis that we included in the study. Pelucha, Kveton and Jilkov (2013) also suggest that statistical analyses should contain data on actual 
payments, not budget allocations, as presented in study by Shucksmith, Thomson, and Roberts (2005), which could lead to measures of the real impact of the public support in the regions. Our analysis therefore covered the real expenditure of funds for individual priority axes in the programmes of both policies in the 2007-2015 programming period (in accordance with the $\mathrm{N}+2$ rule), and the change in socioeconomic features at the local (powiat, NUTS4) level in this period. The Pearson correlation coefficient was used to assess the relationship between the level of per capita expenditure on RDP and ROP and selected indicators describing the level of economic, social and demographic development of local government units. The intervention logic of the both programmes as a set of programme-specific intervention areas are shown in Table 1, while Tables 2-4 show the set of local characteristics used in analysis of the social, economic and infrastructural change in the local dimension.

Table 1. Intervention logic of rural and regional programmes

\begin{tabular}{|c|c|c|}
\hline Type & Variable & Symbol \\
\hline \multirow{9}{*}{ 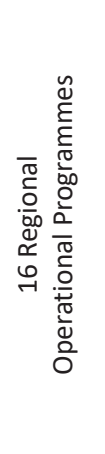 } & Theme 1. R\&D, technology, innovations, entrepreneurship & ROP_1 \\
\hline & Theme 2. Information society & ROP_2 \\
\hline & Theme 4. Environment & ROP_4 \\
\hline & Theme 6. Culture, tourism, international cooperation & ROP_6 \\
\hline & Theme 7. Cities, Towns, spatial revitalisation, & ROP_7 \\
\hline & Theme 8. Technical infrastructure, incl. transport & ROP_8 \\
\hline & Theme 10. Education and human capital & ROP_10 \\
\hline & Theme 11. Healthcare and social infrastructure & ROP_11 \\
\hline & Total - ROP & ROP \\
\hline \multirow{5}{*}{ 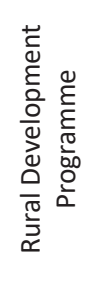 } & $\begin{array}{l}\text { Axis 1. Improving the competitiveness of the agricultural and forestry } \\
\text { sector }\end{array}$ & RDP_1 \\
\hline & Axis 2. Improvement of the environment and the countryside & RDP_2 \\
\hline & Axis 3. Quality of life in rural areas and diversification of rural economy & RDP_3 \\
\hline & Axis 4. Leader & RDP_4 \\
\hline & Total - RDP & RDP \\
\hline
\end{tabular}

Source: MRiRW 2007; MRR 2007.

In the period discussed, per capita expenditures under both programmes show the preferences of the programme impact, and thus, support for modernisation of the agricultural sector and improvement of environmental techniques and 
practices constitute the vast majority of the programme expenditures in the RDP, while ROPs intensively supported development of entrepreneurship and innovation as well as infrastructure, mainly transport infrastructure.

Table 2. Characteristics the local entrepreneurship and infrastructure

\begin{tabular}{|c|c|c|}
\hline Type & Variable & Symbol \\
\hline \multirow{8}{*}{ 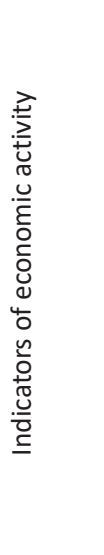 } & Newly registered economic entities (average total 2008-2016) & NEE_t \\
\hline & $\begin{array}{l}\text { Newly registered economic entities (per 10k population, average 2008- } \\
\text { 2016) }\end{array}$ & NEE_10 \\
\hline & Newly registered economic entities (average change 2008-2016) & NEE_d \\
\hline & Economic entities (per 10k population, average 2008-2016) & EE_10 \\
\hline & Economic entities (average change 2008-2016) & EE_d \\
\hline & $\begin{array}{l}\text { Natural persons conducting economic activity (average total number } \\
\text { 2008-2016) }\end{array}$ & $N P_{-} t$ \\
\hline & $\begin{array}{l}\text { Natural persons conducting economic activity (per 10k population, average } \\
\text { 2008-2016) }\end{array}$ & NP_10 \\
\hline & Natural persons conducting economic activity (average change 2008-2016) & NP_d \\
\hline \multirow{12}{*}{ 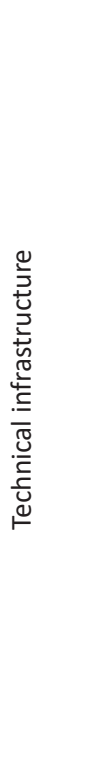 } & Length of the sewerage network in km (average value 2008-2016) & LSN_t \\
\hline & Density of the sewerage network per 100 sq. km (average value 2008-2016) & DSN_t \\
\hline & Length of the sewerage network in km (average change 2008-2016) & LSN_d \\
\hline & Length of the water supply network in km (average value 2008-2016) & LWS_t \\
\hline & $\begin{array}{l}\text { Density of the water supply network per } 100 \text { sq. km (average value } \\
\text { 2008-2016) }\end{array}$ & DWS_t \\
\hline & Length of the water supply network in km (average change 2008-2016) & LWS_d \\
\hline & Length of the gas network in km (average value 2008-2016) & LGN_t \\
\hline & Density of the gas network per 100 sq. km (average value 2008-2016) & DGN_t \\
\hline & Length of the gas network in km (average change 2008-2016) & LGN_d \\
\hline & $\begin{array}{l}\text { Proportion of population using the water supply network (average value } \\
\text { 2008-2016) }\end{array}$ & SWS_t \\
\hline & $\begin{array}{l}\text { Proportion of population using the sewerage network (average value } \\
\text { 2008-2016) }\end{array}$ & SSN_t \\
\hline & Proportion of population using the gas network (average value 2008-2016) & SGN_t \\
\hline
\end{tabular}

Source: Own selection based on: Pelucha, Kveton and Jilkova (2013); Shucksmith, Thomson and Roberts (2005) and Local Data Bank (CSO 2018). 
Table 3. Local financial and territorial characteristics

\begin{tabular}{|c|c|c|}
\hline Type & Variable & Symbol \\
\hline \multirow{11}{*}{ 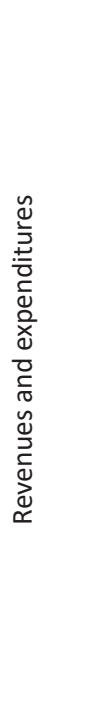 } & Total revenues per capita (average amount in PLN 2008-2016) & TR_t \\
\hline & Own revenues per capita (average amount in PLN 2008-2016) & OR_t \\
\hline & Total revenues per capita (average change 2008-2016) & TR_d \\
\hline & Own revenues per capita (average change 2008-2016) & OR_d \\
\hline & Total expenditures per capita (average amount in PLN 2008-2016) & TE_t \\
\hline & $\begin{array}{l}\text { Total expenditures on education and culture per capita (average amount } \\
\text { in PLN 2008-2016) }\end{array}$ & EEC_t \\
\hline & Total expenditures per capita (average change 2008-2016) & TE_d \\
\hline & $\begin{array}{l}\text { Share of investment expenditures in total expenditures (average value } \\
\text { in PLN 2008-2016) }\end{array}$ & SIE_t \\
\hline & $\begin{array}{l}\text { Share of investment expenditures in total expenditures (average change } \\
\text { 2008-2016) }\end{array}$ & SIE_d \\
\hline & Total expenditures on roads per capita (average amount in PLN 2008-2016) & ER_t \\
\hline & Total expenditures on roads per capita (average change 2008-2016) & ER_d \\
\hline \multirow{6}{*}{$\stackrel{N}{*}$} & Area of agricultural land in ha (2005) & $A A L_{-} t$ \\
\hline & Proportion of agricultural land in total area (2005) & $S A L \_t$ \\
\hline & Population (average value 2008-2016) & POP_t \\
\hline & Place in the ranking in terms of area & RA \\
\hline & Place in the ranking in terms of population & RP \\
\hline & Area in sq. km & $A R \_t$ \\
\hline
\end{tabular}

Source: own selection based on: Pelucha, Kveton and Jilkova (2013); Shucksmith, Thomson and Roberts (2005) and Local Data Bank (CSO 2018).

Table 4. Characteristics of local demography, civic society and human capital

\begin{tabular}{lll}
\hline Type & \multicolumn{1}{c}{ Variable } & Symbol \\
\hline & Age dependency ratio (average value 2008-2016) & AD_t \\
& Age dependency ratio (average change 2008-2016) & AD_d \\
$\frac{\overrightarrow{0}}{\frac{0}{00}}$ & Unemployment rate (average value 2008-2016) & UR_t \\
$\frac{0}{00}$ & Unemployment rate (average change 2008-2016) & UR_d \\
$\frac{0}{0}$ & Net migration rate (migration balance) (average value 2008-2016) & MB_t \\
& Population density per sq. km (average value 2008-2016) & PD_t \\
\hline
\end{tabular}


Table 4 - continued

\begin{tabular}{|c|c|c|}
\hline Type & Variable & Symbol \\
\hline \multirow{9}{*}{ 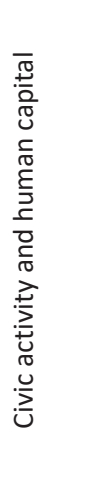 } & Voter turnout in parliamentary elections in 2015 & VT_15 \\
\hline & Voter turnout in EU accession referendum in 2003 & VT_03 \\
\hline & Proportion of "yes" votes in EU accession referendum in 2003 & YES_03 \\
\hline & Number of people with at least secondary education (2011) & SE_t \\
\hline & Number of people with higher education (2011) & HE_t \\
\hline & Proportion of people with at least secondary education (2011) & SSE_t \\
\hline & Proportion of people with higher education (2011) & SHE_t \\
\hline & Number of NGOs (2015) & NGO_t \\
\hline & Number of NGOs per 10k population (2015) & NGO_10 \\
\hline
\end{tabular}

Source: own selection based on: Pelucha, Kveton and Jilkova (2013); Shucksmith, Thomson and Roberts (2005) and Local Data Bank (CSO 2018).

\section{Results}

The distribution of expenditures on respective topics and axes of the ROPs and RDP points to a major role of regional programmes, which between 2007 and 2015 spent on average of PLN 3,400 per capita, compared to PLN 1,900 of expenditure under the RDP. It should, however, be remembered that RDP is complementary to the instruments of the first pillar of the CAP in Poland, which results from the division of funds between them. As a result, many areas of development of technical, social and rural infrastructure on rural areas are supported by the ROPs (Figure 1).

The question remains about the nature of dependencies between respective support areas and expenditures under the two programmes analysed. Analysis of changes in socio-economic and infrastructure characteristics (place-based) at the level of powiats and their correlation with RDP expenditures and 16 ROPs in various areas makes it possible to create a matrix of impact.

Tables 5-7 show that 16 ROPs positively correlate with the size of the powiat measured by population, features in the economic activity category, the level of investment expenditure (but to a lesser extent), unemployment (negative correlation), the condition of technical infrastructure development and human and civic capital.

The study showed that in the case of RDP there was a positive correlation between its expenditures and the size (area) of the administrative unit, the area of agricultural land in the powiat, the growth rate of the number of natural persons 
conducting economic activity, total incomes and expenditures of local government units and the level of technical infrastructure development.

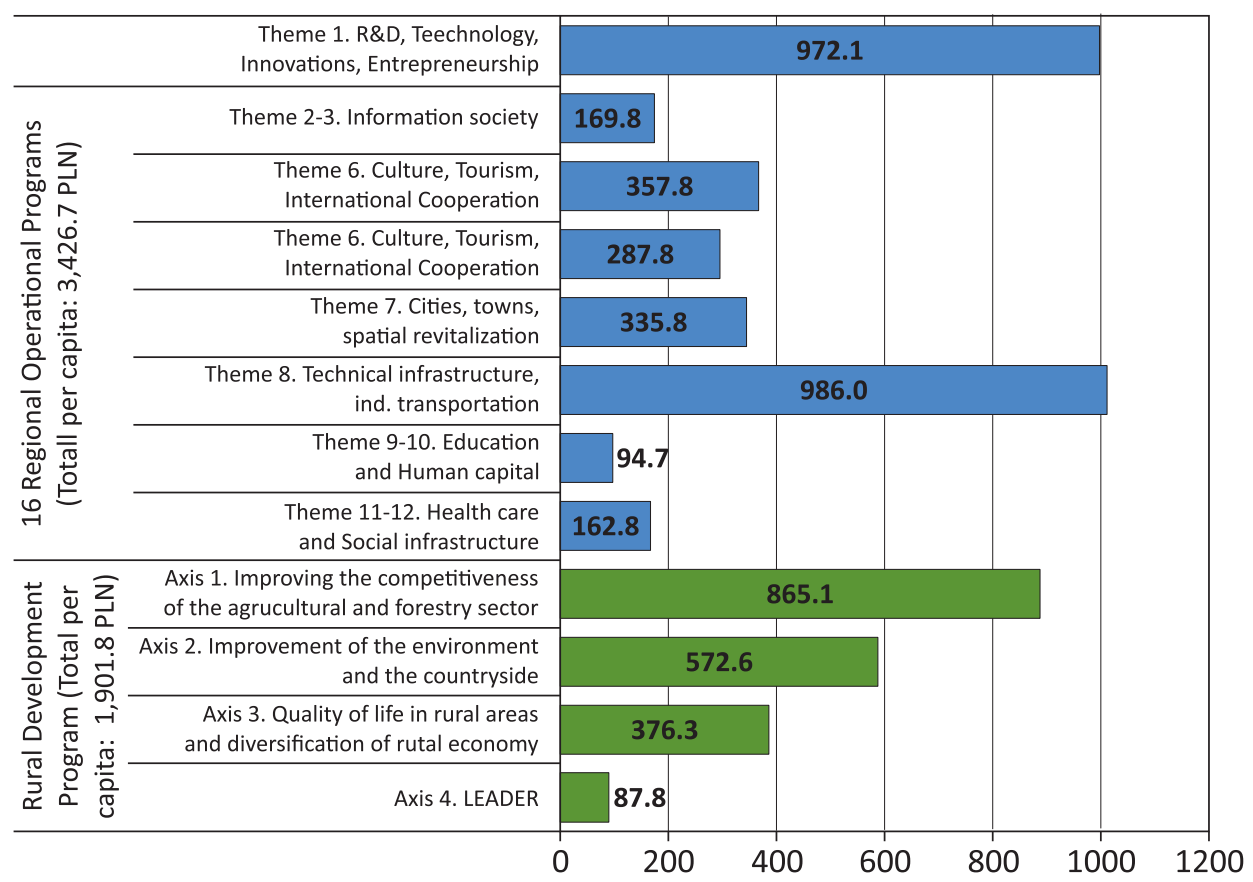

Figure 1. Per capita expenditures for RDP and ROP 2007-2015 (in PLN)

Source: Own calculations based on SIMIK database and Local Data Bank by CSO.

It should be emphasised that in the case of links between the development of socio-economic features of the region and per capita expenditures related to the implementation of the rural development policy, these relationships are the strongest for powiats with a large proportion of arable land. This is related to RDP expenditures on agri-environmental measures and payments to farms located in less-favoured areas (LFA). It is interesting to note that in addition to Axis $4 \mathrm{RDP}$ - Leader, expenditure within all remaining RDP axes had a very strong relationship with the area of land in agricultural use in the total area of a territorial unit. In addition, a positive impact of the RDP funds was observed on some aspects of local development related to the development of economic activity, especially in the case of average change in the number of natural persons conducting economic activity in 2008-2016. The analysis of the survey results clearly showed positive links between RDP expenditures and the development of the water-supply network and gas network in rural areas. 


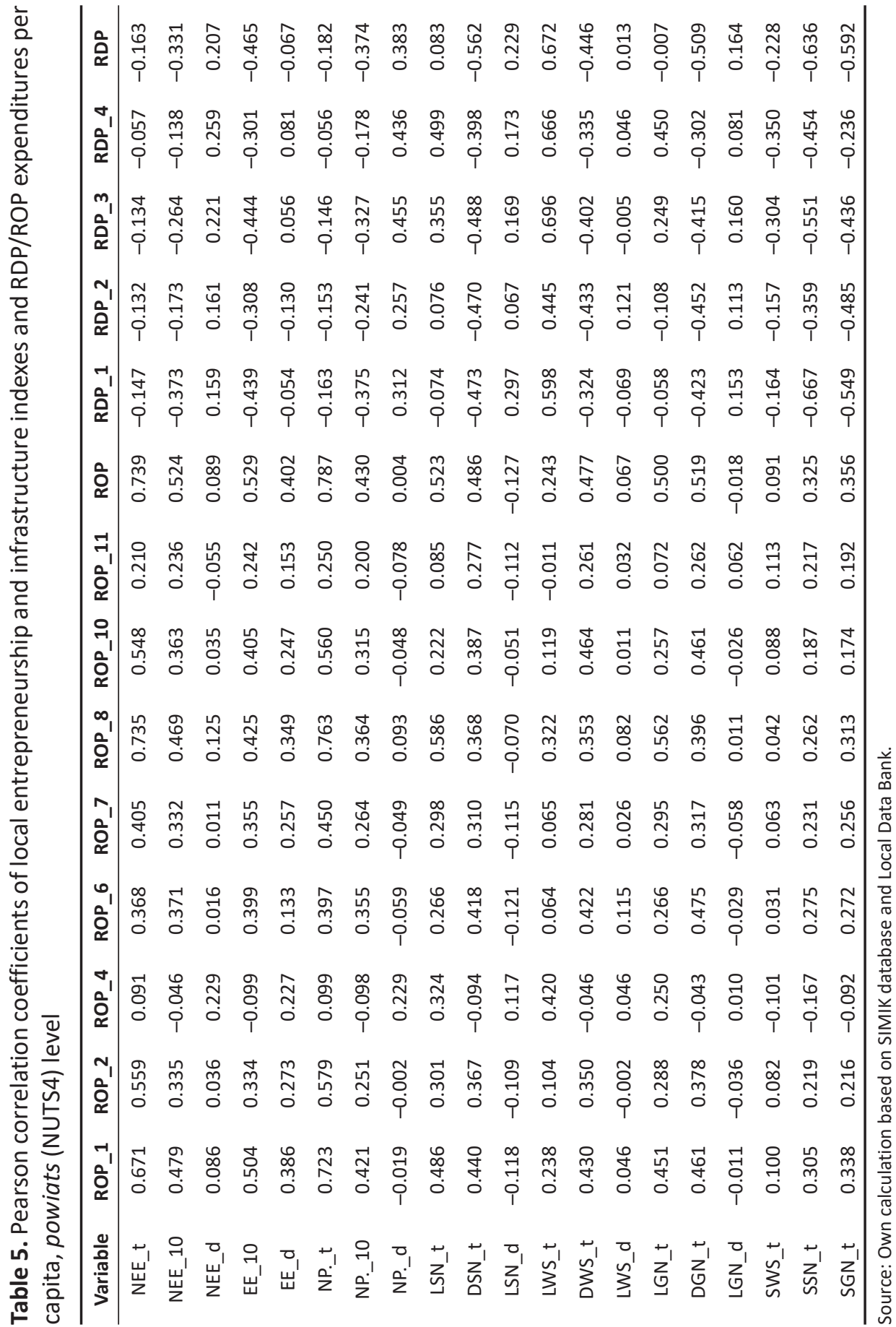




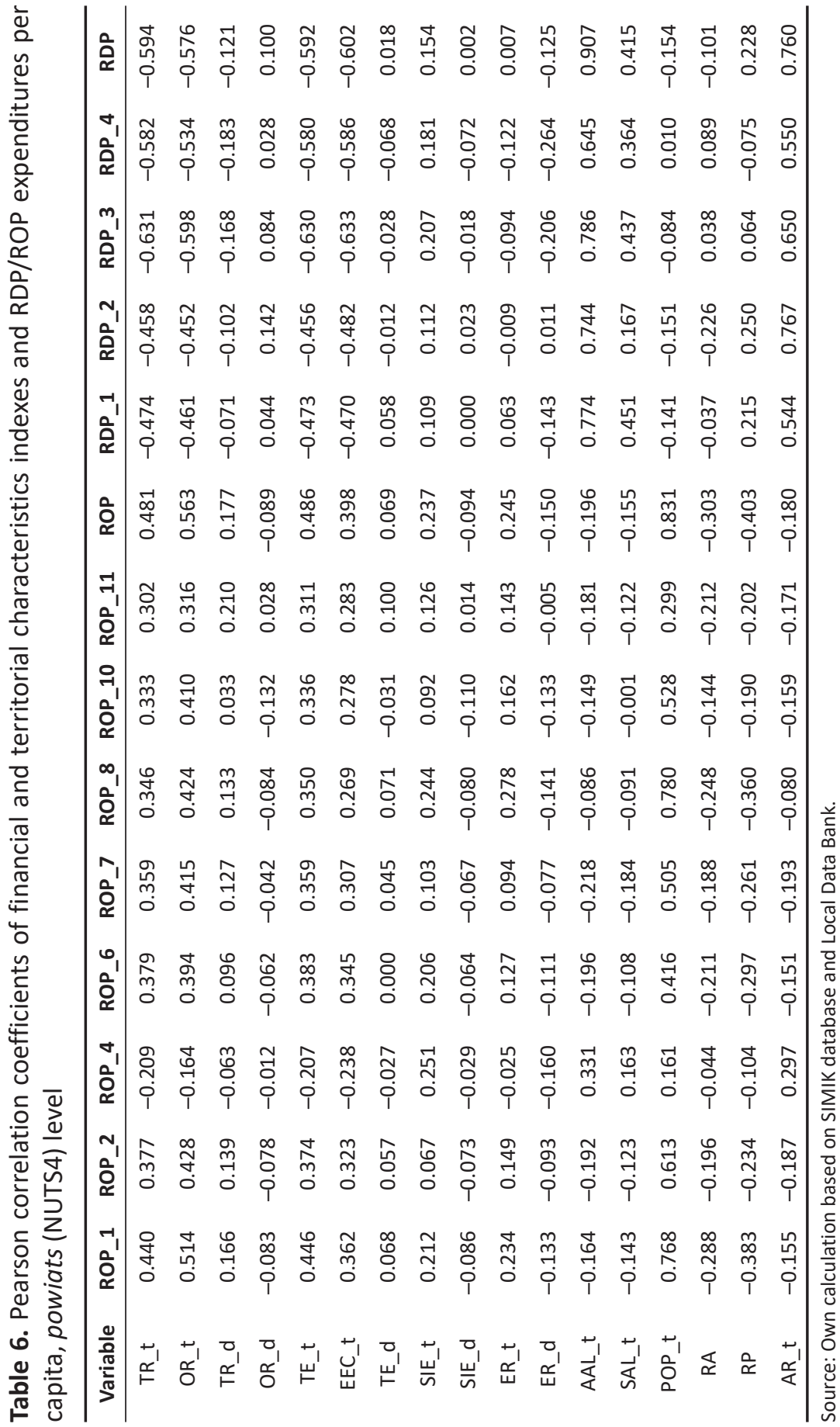




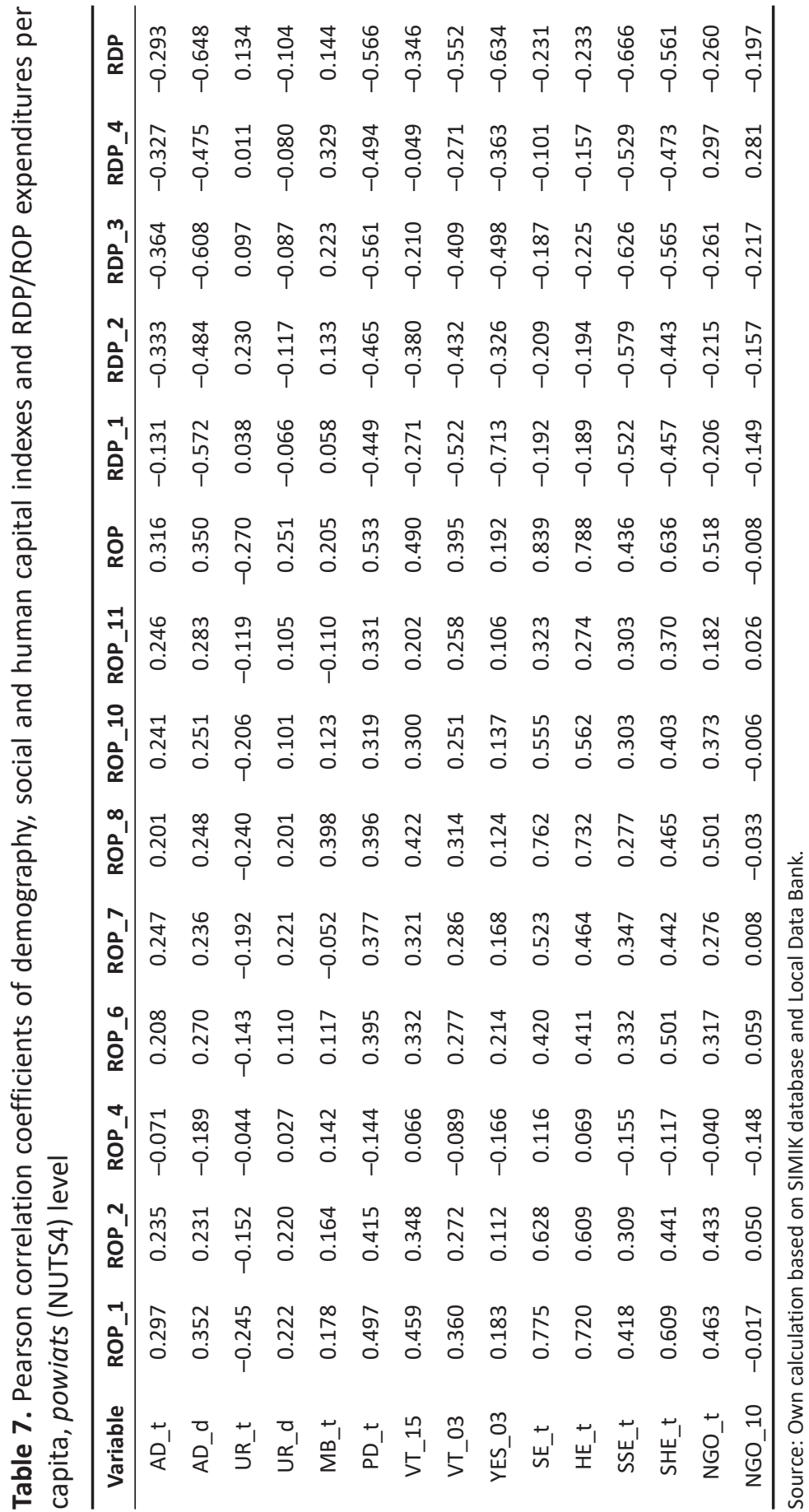


There was also a positive impact of support under the ROP on the decrease in unemployment at the powiat NUTS4 level (i.e. negative correlation between expenditures and the local unemployment rate).

In particular, it should be emphasised that, due to their quite extensive scope, covering various issues of socio-economic life at the regional level, the financial expenditures of regional programmes were relatively more often reflected in changes in selected socio-economic indicators.

The ROP positively influenced the development of education (changes in the number of people with secondary and higher education), the increase in the number of natural persons conducting economic activity, or increases in the number of new business entities.

Due to the method of calculating the allocation of regional policy, the study showed a natural relationship between the volume of outlays from the ROP and the number of residents in the region. It was shown that some synergies of the impact of both programmes can be seen in the development of water-supply systems in the regions. Both programmes contributed to the development of the length of the water supply network (absolute increase in $\mathrm{km}$ ). Both programmes related to the size of powiats (especially ROP) and the amount of agricultural land (RDP) and the number of inhabitants in the area.

The study confirms the high synergy effect of their impact. Similar conclusions can be drawn from the research conducted with representatives of the local authorities, who pointed to the good organisation of the planning process, social consultations and inter-sectoral cooperation in the process of creating policy documents in the region (Chmieliński et al. 2017). Other studies of this type indicate the need to maintain and increase the "place-specific" process in designing non-governmental solutions for economic development policy at the regional level (including those related to rural development). Drawing attention to regional specificity and unique local needs may be a key factor in further improving the impact of EU policies on reducing regional disparities and improving the quality of life and the level of convergence in the European regions.

\section{Discussion}

From the point of view of rural development, synchronisation of the cohesion policy and the Common Agricultural Policy should continue to include areas related to improving the quality of human capital in the countryside and to creating infrastructure-strengthening economic cohesion between the countryside and the city - this mainly concerns transport networks. Such an approach may contribute to increasing employment of the rural population in the cities, while curbing 
rural depopulation tendencies. This may contribute to the economic revival of rural areas, whose residential functions will affect the development of the service and trade network. An equally important task of cohesion policy in the future should be to support the conservation of cultural heritage and natural resources in rural areas, which is one of the key elements of tourism development in the region.

At the level of the institutional system, the cohesion-policy measures implemented under the Common Agricultural Policy and relating to non-agricultural functions of rural areas could be executed at the regional level, and Poland's experience in the implementation of the ROPs confirm the need to transfer development programming and financial instruments implementation to the NUTS2 level, which is linked with further strengthening of regional governance, while making the decision-making processes regarding the directions of support more flexible (Chmieliński et al. 2018a). It can only be assumed that a degree of flexibility related to adapting the instruments to specific regional needs and the possibility of reacting to the changing reality (in this context, the seven-year planning perspective is a major challenge) is not possible in the case of RDP, set at the national level in Poland. This analysis indicates that what should be considered is the possibility of introducing regional RDPs operated by the same institutions as regional programmes. Simultaneously, work on strengthening the regional governance of public policy should be carried out through building horizontal networks (cooperation at the level of administration and public services) and vertical cooperation (with residents and local organisations). Paradoxically, in Poland it is Leader - the RDP measure - that is a tool for creating local governance; it has fostered dialogue between local governments (administration) and representatives of residents, social organisations and entrepreneurs, and at the same time formulation of local needs. Many of these, which were handled as part of local development strategies, have been permanently included in the local public policy (Chmieliński et al. 2018b).

The lessons learned by the European Union countries during the Leader programme implementation, suggest the need to develop clear regulations leading to an increase in the importance of social and private partners in the programming process and the implementation of cohesion policy at the regional level. Unfortunately, Leader has never gone beyond the "laboratory" phase of rural development (Hodge and Midmore 2008; Ray 1996), although it has provided extensive grounds to conclude that rural development policy can be most effectively executed through cooperation between actors as part of a three-sector partnership based on the definition of sub-objectives and their implementation at local level (Chmieliński et al. 2018b). An attempt to translate the Leader philosophy onto a regional level should form the basis for the future economic development of the EU, while ensuring 
the right balance between competitiveness and cohesion of the European regions. Bearing in mind that the recent enlargements of the EU to include the countries of Central and Eastern Europe have widened the gap between its regions, it should be recognised that sustainable development of the EU territory can only be realised at the regional level, giving local actors in individual member states the opportunity to determine the proportion between investment expenditures boosting the competitiveness of a given area. For some regions, such an objective may mean an increase in expenditures on research and innovation, for others it may mean investment in social and technical infrastructure, fostering improvement of territorial cohesion at the regional and supra-regional level. The elements of this cohesion include the improvement of communication networks linking rural areas with conurbations in order to enable rural residents access the labour market without the need to change their place of residence. On the one hand, this contributes to curbing rural depopulation tendencies, it is an opportunity to tap into the potential of human resources in the development of cities, which are growth centres, and on the other it may result in the development of the commercial and service infrastructure for the needs of rural residents.

The European value added of cohesion policy creates an approach according to which strategic goals, relying on long-term planning going beyond subsequent programming periods and short-term political interests of the respective member states are implemented, taking into account local needs in different areas of Europe. Future programming of rural development and regional development should therefore be based on a bottom-up approach, whose direction would be set out in strategic goals defined at the European level. In the light of this philosophy, cohesion policy may define a range of measures that are key to the future development of the territory of the EU, bearing in mind the need to equalise the opportunities of less developed regions. Simultaneously, the burden of planning should be shifted to the lowest defining unit of its area, and, where possible, implementation and management of funds should devolve to the regional level.

In the next programming period, beyond 2020, member states will be able to transfer cohesion-policy resources to another EU instrument to fund a project (on a voluntary basis and within certain limits). In this case, the rules of the other instrument apply. Conversely, member states will be allowed also to choose to use their cohesion-policy funds to finance a project selected under another EU budget tool. If implemented, this rule could facilitate better planning and implementation of the regional and local policies, close to a place-based approach and with respect to rural-regional characteristics (EC 2018). Although simplification and subsidiarity will play a significant role in future, the Common Agricultural Policy (cf. Hogan 2018) will still retain its very sectoral character, so one can expect the cohesion 
policy to take a broader approach to territorial development in individual EU regions.

\section{Conclusions}

Rural areas in Poland and in the European Union constitute a demographic reservoir of human capital for the economy (in Poland, rural areas account for $93 \%$ of the country's surface, inhabited by nearly 15 million people, which accounts for almost $40 \%$ of the population), which forms the basis for long-term sustainable development (Sikorska 2007; Wilkin and Nurzyńska 2016).

The article has analysed the complementarity of cohesion policy and rural policy (RDP) instruments in terms of their impact on socio-economic development at the local level. The analysis made it possible to indicate several regularities. First, analysis of 16 ROPs showed their positive impact on the development of economic activity, capital expenditure in the powiats and improvement of infrastructure. It is worth noting the positive correlation with the indicators of the development of human capital and a negative correlation with the level of unemployment. Second, the volume of expenditures within regional programmes is closely related to population size. For rural policy, support under its instruments was related to the physical size of the region, including the area of land used for agriculture. At the same time, the identified effects of the instruments of both policies are complementary. Third, there was also a positive correlation between RDP expenditures and the growth rate of the number of natural persons conducting economic activity, total incomes and expenditures of local government units and the level of technical infrastructure development.

Better interaction between the two policies is observed at the regional level, and cohesion policy should emphasise the use of the rural potential by supporting equalisation of educational opportunities, development of non-agricultural business activities and investment in transport infrastructure linking rural areas with conurbations to enable rural residents to benefit from the widest possible geographical access to the labour market without the need to change their place of residence.

\section{Acknowledgements}

The authors would like to thank the participants in special session S13-S2: Cohesion Policy and European Identity during the $58^{\text {th }}$ ERSA Congress, $28^{\text {th }}-31^{\text {st }}$ August 2018, Cork, Ireland and the $16^{\text {th }}$ ERDN Conference, 7-9 September 2018, Cluj-Napoca, Romania, for valuable discussion and comments on earlier versions of this paper. 


\section{Bibliography}

Barca F. (2009). An Agenda for a Reformed Cohesion Policy: A Place-based Approach to Meeting European Union Challenges and Expectations. Independent report prepared at the request of Danuta Hübner, Commissioner for Regional Policy, April 2009.

Barca F., McCann P., Rodríguez-Pose A. (2012). The case for regional development intervention: Place-based versus place-neutral approaches. Journal of Regional Science, 52 (1), 134-152.

Becker S., Egger P., von Ehrlich M. (2010). Going NUTS: The effect of EU Structural Funds on regional performance. Journal of Public Economics, 94 (9-10), 578-590.

Brasili C., Fanfani R. (2007). Regional Differences in Agriculture and Rural Areas: The Italian and Chinese Case Studies. Paper Presented at FAO, Rome. Rome: Food and Agriculture Organization of the United Nations (FAO).

Charron N., Dykstra L., Lapuente V. (2013). Regional governance matters: Quality of government within European Union Member States. Regional Studies, 48 (1), 68-90.

Charron N., Lapuente V., Rothstein B. (2013). Quality of Government and Corruption Form a European Perspective: A Comparative Study of Good Government in EU Regions. Cheltenham-Northampton: Edward Elgar Publishing.

Checkel J.T. (2005). International institutions and socialization in Europe: Introduction and framework. International Organization, 59 (4), 801-826.

Chmieliński P., Cox A., Leonard A., Torrisi G., Tudor M.M. (2018a). Policy Report: Spatial Determinants of Policy Performance and Synergies. PERCEIVE Project Report "Perception and Evaluation of Regional and Cohesion Policies by Europeans and Identification with the Values of Europe", GA no. 693529. Portsmouth: Portsmouth Business School, University of Portsmouth.

Chmieliński P., Faccilongo N., Fiore M., La Sala P. (2018b). Design and implementation of the Local Development Strategy: A case study of Polish and Italian Local Action Groups in 2007-2013. Studies in Agricultural Economics, 120, 25-31.

Chmieliński P., Wieliczko B., Wasilewski A., Wigier M., Gospodarowicz M., Floriańczyk Z. (eds.) (2017). Report on the Policy Recommendations on how to Integrate Cohesion Policy with Urban and Rural Policies. PERCEIVE Project Report "Perception and Evaluation of Regional and Cohesion Policies by Europeans and Identification with the Values of Europe", GA no. 693529. Warsaw: Instytut Ekonomiki Rolnictwa i Gospodarki Żywnościowej-Państwowy Instytut Badawczy.

Collins A., Leonard A., Cox A., Greco S., Torrisi G. (2017). Report on the Synergies between EU Cohesion Policy and Rural Development Policies: Deliverable 4.2. PERCEIVE Project "Perception and Evaluation of Regional and Cohesion Policies by Europeans and Identification with the Values of Europe", GA no. 693529. Portsmouth: University of Portsmouth.

Crescenzi R., De Filippis F., Pierangeli F. (2015). In tandem for cohesion? Synergies and conflicts between regional and agricultural policies of the European Union. Regional Studies, 49 (4), 681-704. 
Crescenzi R., Giua M. (2014). The EU cohesion policy in context: Regional growth and the influence of agricultural and rural development policies. LEQS Discussion Paper Series, 85. London: London School of Economics.

CSO (2018). Local Data Bank. Statistics Poland - Central Statistical Office (CSO), https:// bdl.stat.gov.pl/BDL/start [accessed: 09.05.2018].

EC (European Commission) (2018). EU budget for the future: Regional Development and Cohesion. Brussels: European Commission.

Esposti R. (2008). Reforming the CAP: An agenda for regional growth? Paper prepared for the $109^{\text {th }}$ EAAE Seminar "The CAP after the Fischler reform: National implementations, impact assessment and the agenda for future reforms", Viterbo, Italy, $21^{\text {st }}-22^{\text {nd }}$ November 2008.

Hodge I., Midmore P. (2008). Models of rural development and approaches to analysis evaluation and decision-making. Économie Rurale, 307, 23-38.

Hogan Ph. (2018). Remarks by Commissioner Phil Hogan on Simplification and Subsidiarity. July AGRI Council, Brussels, $17^{\text {th }}$ July, 2018, https://ec.europa.eu/commission/commissioners/2014-2019/hogan/announcements/remarks-commissioner-phil-hogan-simplification-and-subsidiarity-july-agri-council-brussels_en [access: 12.12.2018].

Lagendijk A., Cornford J. (2000). Regional institutions and knowledge: Tracking new forms of regional development policy. Geoforum, 31 (2), 209-218.

Le Gallo J., Dall'Erba S., Guillain R. (2011). The local versus global dilemma of the effects of structural funds. Growth and Change, 42 (4), 466-490.

Monasterolo I. (2012). Analysing the effect of the EU membership on urban and rural areas: The case of Hungary. Rural Areas and Development, 9, 173-194.

MRiRW (Ministerstwo Rolnictwa i Rozwoju Wsi) (2007). Program Rozwoju Obszarów Wiejskich 2007-2013. Warsaw: Ministerstwo Rolnictwa i Rozwoju Wsi.

MRR (Ministerstwo Rozwoju Regionalnego) (2007). Narodowe Strategiczne Ramy Odniesienia 2007-2013. Warsaw: Ministerstwo Rozwoju Regionalnego.

Pelucha M., Kveton V., Jilkova J. (2013). Territorial dimensions of agro-environmental measures and LFA in rural development policy in the Czech Republic. Land Use Policy, 34, 91-103.

Ray Ch. (1996). The Dialectic of Local Development: The Case of EU Leader 1 Rural Development Programme. Centre for Rural Economy Working Paper Series, 23, 1-37. Newcastle upon Tyne: University of Newcastle upon Tyne.

Roberts P. (1993). Managing the strategic planning and development of regions: Lessons from a European Perspective. Regional Studies, 27, 759-768.

Shucksmith M., Thomson K., Roberts D.J. (eds.). (2005). The CAP and the Regions: The Territorial Impact of the Common Agricultural Policy. Oxford: CABI Publishing.

Sikorska A. (2007). Przeobrażenia w strukturze społeczno-ekonomicznej wsi a proces właczania się Polski do Wspólnej Polityki Rolnej. Warsaw: Instytut Ekonomiki Rolnictwa i Gospodarki Żywnościowej-Państwowy Instytut Badawczy.

Suddaby R., Greenwood R. (2005). Rhetorical strategies of legitimacy. Administrative Science Quarterly, 50 (1), 35-67. 
Tacoli C. (ed.) (2006). The Earthscan Reader in Rural-Urban Linkages. London: Taylor \& Francis Ltd, Earthscan Ltd.

Wilkin J., Nurzyńska I. (eds.) (2016). Polska wieś 2016: Raport o stanie wsi. Warsaw: Fundacja na Rzecz Rozwoju Polskiego Rolnictwa (FDPA), Wydawnictwo Naukowe Scholar.

\title{
Regionalne podejście do rozwoju obszarów wiejskich? Studium regionalnych i wiejskich programów rozwoju w latach 2007-2015 w Polsce
}

\begin{abstract}
Streszczenie: W pracy badamy rolę czynników strukturalnych (ściślej tzw. place-based characteristics) w kształtowaniu polityki UE. Analizą objęto rzeczywiste wydatki na poszczególne osie priorytetowe w programach dwóch polityk sektorowych w okresie programowania 2007-2013 oraz zmiany cech społeczno-gospodarczych na poziomie lokalnym (powiatowym, NUTS4). Współczynnik korelacji Pearsona posłużył do oceny zależności między poziomem wydatków na PROW i RPO na 1 mieszkańca oraz wybranymi wskaźnikami opisującymi poziom rozwoju gospodarczego, społecznego i demograficznego jednostek samorządu terytorialnego. Pokazujemy, że instrumenty polityki rozwoju obszarów wiejskich i programów regionalnych w latach 2007-2013 były komplementarne względem siebie, ale także silnie związane z cechami regionu (takimi jak wielkość fizyczna, stan ludności, powierzchnia użytków rolnych), a zatem silnie uzależnione od specyficznych cech danego terytorium. Sugerujemy, że w przyszłej polityce wiejskiej większy nacisk powinno się położyć na regionalne i lokalne (tzw. place-based) uwarunkowania rozwoju.
\end{abstract}

Słowa kluczowe: polityka regionalna, WPR, komplementarność, analiza regionalna, polityka publiczna, program rozwoju obszarów wiejskich, regionalny program operacyjny, 2007-2013, Polska. 